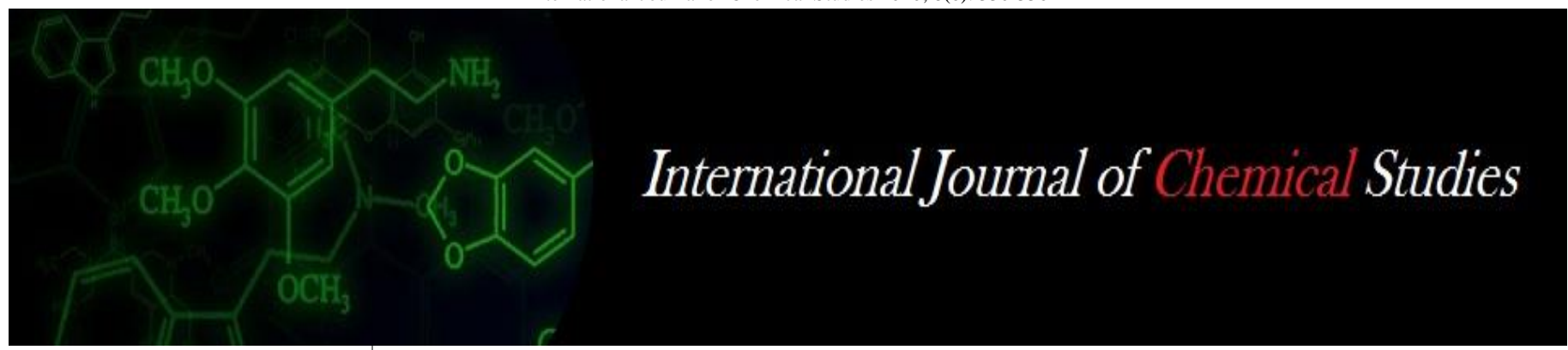

P-ISSN: 2349-8528

E-ISSN: 2321-4902

www.chemijournal.com

IJCS 2020; 8(6): 330-336

(C) 2020 IJCS

Received: 18-08-2020

Accepted: 16-10-2020

Gagendra Singh Rajput

Department of Biological

Sciences, Sam Higginbottom

Institute of Agriculture,

Technology \& Sciences (Deemed-

to be University), Allahabad,

India

\section{PW Ramteke}

Department of Biological

Sciences, Sam Higginbottom

Institute of Agriculture,

Technology \& Sciences (Deemed-

to be University), Allahabad,

India
Corresponding Author: Gagendra Singh Rajput Department of Biological Sciences, Sam Higginbottom Institute of Agriculture, Technology \& Sciences (Deemedto be University), Allahabad, India

\section{Biochemical parameters and yield attributes of tomato (Lycopersicon esculentum Mill.) as influenced by plant growth promoting Rhizobacteria with organic and inorganic use of nutrients}

\section{Gagendra Singh Rajput and PW Ramteke}

DOI: https://doi.org/10.22271/chemi.2020.v8.i6e.10789

\begin{abstract}
PGPR are beneficial rhizospheric bacteria that can mobilize and solublize nutrient that plant can utilize, plant can uptake under some adverse conditions. PGPR promote plant growth by directly affect the metabolism of the plants by providing substances that are usually in short supply. The present investigation was carried to find out the impact of different PGPR along with organic and inorganic nutrients on plant biological parameters and crop yield at Department of Biological Sciences, Sam Higginbottom Institute of Agriculture, Technology and Sciences (Deemed-to-be University) Allahabad, during Rabi season 2015-16. Tomato plants variety NTL-186 was transplanted in pot during 2nd week of Fabuary. The experiment was carried out using 11 treatments with three replication on completely randomized design. There were five different PGPR are selected namely (PR3, PR5, PR6, PR24 and PR29) along with FYM 10 t/ha and Fertilizer dose (NPK) 120:60:50 NPK- kg/ha. Results revealed that PGPR strain PR6 along with T7 [NPK (100\%) and FYM (100\%)] showed the highest chlorophyll 'a' $(2.12 \mathrm{mg} / \mathrm{g} / \mathrm{Fw})$, cholophyll 'b' $(2.02 \mathrm{mg} / \mathrm{g} / \mathrm{Fw})$, total chlorophyll $(4.14 \mathrm{mg} / \mathrm{g} / \mathrm{Fw})$ and Carotenoid $(2.06$ $\mathrm{mg} / \mathrm{g} / \mathrm{Fw})$, no. of fruit per plant (17.00), fresh fruit weight $(718.33 \mathrm{~g} / \mathrm{plant})$ obtained all the data were statistically significant, over control. From the present investigation it was concluded that $\mathrm{T}_{7}$ (PR6 + NPK $(100 \%)+$ FYM (100) \%) was found most effective which significantly increased the biochemical parameters and yield of Tomato (Lycopersicon esculentum Mill.).
\end{abstract}

Keywords: Tomato, PGPR, FYM, N.P.K., chlorophyll and carotenoid

\section{Introduction}

Tomato (Lycopersicon esculentum Mill.) belongs to family solanaceae having chromosome number $(2 n=24)$. Officially the cultivated tomato belongs to the order Scrophulariales, suborder Solanineae, family Solanaceae, tribe Solaneae, genus Lycopersicon, subgenus Eulycopersicon, species Lycopersicon esculentum (lycopersicon $=$ wolf peach, esculentum $=$ edible). It is a self pollinated crop and Peru-Equador region is considered to be the centre of origin. it can also be identified as Solanum lycopersicon, as originally classified by Linnaeus in 1753 , because of the similarity between tomatoes and potatoes. Tomato was introduced by the Portuguese. This fruit contains a variety of micro components, such as lycopene (an antioxidant), potassium, vitamins (A, C, E and $\mathrm{K}$ ), sucrose and folic acid (Peralta and spooner, 2007) ${ }^{[6]}$

It contributes to a healthy, well-balanced diet. They are rich in minerals, vitamins, essential amino acids, sugars and dietary fibres. Tomato contains much vitamin $\mathrm{B}$ and $\mathrm{C}$, iron and phosphorus. Tomato fruits are consumed fresh in salads or cooked in sauces, soup and meat or fish dishes. They can be processed into purées, juices and ketchup. Canned and dried tomatoes are economically important processed products. Yellow tomatoes have higher vitamin A content than red tomatoes, but red tomatoes contain lycopene, an anti-oxidant that may contribute to protection against carcinogenic substances. (Naika et al., 2005) ${ }^{[5]}$

Plant growth-promoting bacteria (PGPB) are defined as free-living soil, rhizosphere, rhizoplane, and phylosphere bacteria that, under some conditions, are beneficial for plants Most of the activities of PGPB have been studied in the rhizosphere, and to lesser extent on the 
leaf surface; endophytic PGPB that reside inside the plant have also been found. PGPB promote plant growth in two different ways: (1) They directly affect the metabolism of the plants by providing substances that are usually in short supply. These bacteria are capable of fixing atmospheric nitrogen, of solubilizing phosphorus and iron, and of producing plant hormones, such as auxins, gibberellins, cytokinins, and ethylene. Additionally, they improve a plant's tolerance to stresses, such as drought, high salinity, metal toxicity, and pesticide load. One or more of these mechanisms may contribute to the increases obtained in plant growth and development that are higher than normal for plants grown ussnder standard cultivation conditions. However, these bacteria do not enhance the genetic capacity of the plant, as genetic material is not transferred. (2) A second group of PGPB, referred to as biocontrol-PGPB, indirectly promote plant growth by preventing the deleterious effects of phytopathogenic microorganisms (bacteria, fungi, and viruses). They produce substances that harm or inhibit other microbes, but not plants. (Hillel., 2005) ${ }^{[2]}$

Organic manuring is becoming an important component of environmentally sound Sustainable agriculture. Residual nature of organic sources makes them more value based for the whole system compared to individual crops. Organic materials hold great promise as a source of multiple nutrients and ability to improve soil characteristics. Recently, the use of organic materials as fertilizers for crop production has received attention for sustainable crop productivity. In organic production system, organic wastes and other biological materials, as available in situ are utilized along with beneficial microbes to release the nutrients to crops. (Jenny and Malliga, 2016) ${ }^{[3]}$

Plant growth promoting rhizobacteria are colonized bacterial species that has the capability to improve plant growth by certain direct and indirect means. Environmental factors including both biotic and abiotic stresses are among the major constraints to crop production. In the current study, the effectiveness of microbial inoculation (Bacillus megaterium) for enhancing growth of tomato plants under salt stress conditions has been investigated. Significant improvement in shoot length, root length, leaf surface area, number of leaves, total weight of the shoot and root was observed in tomato plants inoculated with $\mathrm{zm} 7$ strain post 15 and 30 days of its application. $\mathrm{Zm} 3, \mathrm{Zm} 4$ and $\mathrm{Zm} 6$ strains improved the morphological parameters as compared to the control. Chlorophyll content a, chlorophyll content b, anthocyanin and carotenoid content was increased in tomato plants subjected to $\mathrm{Zm} 7, \mathrm{Zm} 6$ and Zm4 strains. Stress responsive genes; metallothionein and glutothion gene were found highly expressed in $\mathrm{Zm} 7$ treated tomato plants as compared to control, untreated plants. Significant correlation of anthocyanin was reported for carotenoids, chlorophyll-b, shoot weight and total weight of seedling while carotenoids was significantly correlated with leaf surface area, root length, chlorophyll-b and anthocyanin. Overall, Zm7 strain proved best for improvement in salt sressed plant's morphological parameters and biochemical parameters as compared to control, untreated plants. (Ali, et al., 2016) ${ }^{[1]}$. However we hypothesized that combined application of PGPR and organic and Inorganic use of nutrients can enhance the biochemical parameters (chlorophyll a, b, carotenoids). Keeping these all point in mind the present investigation was carried out to study the impact of different levels of PGPR, organic and inorganic uses of nutrients on plant chlorophyll $a, b$, carotenoids contents and yield and yield attributes of Tomato.

\section{Materials and Methods Site descriptions}

The pot experiment was conducted during year 2015-16 at in the month of January to April in Department of Biological Sciences, Allahabad School of Agriculture SHIATS, Allahabad. Allahabad is situated in the agro-climatic zone (Sub-tropical belt) of Uttar Pradesh. The study area falls under sub-tropical climate and is located in between 25.870 North latitude and 81.250 E longitudes at an altitude of 98 meter above the mean sea level (MSL). The maximum temperature of the location reaches up to $460 \mathrm{C}$ to $480 \mathrm{C}$ and seldom falls as low as $40 \mathrm{C}$ to $50 \mathrm{C}$. The Relative humidity ranged between 20 to $94 \%$. The average rainfall in this area is around $850-1100 \mathrm{~mm}$ annually.

\section{Experiment and treatment details}

Soil samples were collected from the surface $(0-15 \mathrm{~cm})$ in the field, (unless you are looking at sub-soil properties). The soil is then sieved through a screen or plastic sieve with a mesh of approximately $5 \mathrm{~mm}$ openings to remove rocks, clods and large pieces of organic matter uniform soil mixture within about 3-4 $\mathrm{cm}$ of the top of the pot. Only healthy and uniform seedlings were transplanted in the evening. Seedlings were transplanted 3-4 $\mathrm{cm}$ deep in pots. Three seedlings per pot were transplanted. Light irrigation given after completion of transplanting. The experiment was conducted with three replication in randomized block design along with eleven treatments (Table 1 and 2) with five selected PGPR namely (PR3, PR5, PR6, PR24 and PR29Tomato plant verity NTL186 was transplanted in pot in rabi season on second week of February 2016. The organic manure applied was FYM 10 t/ha were well incorporated in the experimental (pots) field 10 days before transplanting of seedling. According to the treatment the NPK fertilizer (NPK 120:60:50kg/ha) are applied before transplanting. The treatment combination of PGPR with FYM and NPK are presented in table 2.

\section{Laboratory analysis \\ Biochemical parameters \\ Total chlorophyll content}

The method of Arnon (1949) was followed for estimating chlorophyll a, chlorophyll b and total chlorophyll contents. Leaves were collected from each pot. They were cut into small pieces and $0.25 \mathrm{~g}$ of fresh weight of leaf was weighed from each sample and homogenized with pure acetone. The extract was filtered through watt man No.1 filter paper and washed 2-3 times using 80 per cent acetone. Finally, the volume of the extract was made up to $25 \mathrm{ml}$. The absorbance of the extract was read at 645 and $663 \mathrm{~nm}$ in spectrophotometer and for blank, 80 per cent acetone was used.

\section{Carotenoid}

Carotenoid was estimated according to method Arnon (1949). The leaves were collected for the carotenoid content estimation. Fresh leaves weighing of $0.5 \mathrm{gm}$ was taken and homogenized in $10 \mathrm{ml}$ of acetone (80\% acetone) and centrifuged at $3000 \mathrm{rpm}$ at $10 \mathrm{~min}$. The absorbance was recorded at $470 \mathrm{~nm}$.

Total carotenoid $=[1000 \mathrm{~A} 470-(2.270 \mathrm{Chl}-\mathrm{a}-81.4 \mathrm{Chl}-$ b)]/227

\section{Yield and yield attributes}

All the fruits from three selected plants from each replication of all the treatments were counted at 60 days after 
transplanting. The average total number of fruits per plant of each replication was recorded and subjected to statistical analysis. All the fresh fruits from three selected plants from each replication of all the treatments were weight after picking. The average fresh fruits weight per plant of each replication was recorded and subjected to statistical analysis.

\section{Statistical analysis}

In the present experiment, completely randomized design (CRD) was applied. The analysis of variance technique was applied for drawing conclusions from the data. The calculated value of $\mathrm{F}$ was compared with tabulated value at $5 \%$ level of probability for the appropriate degree of freedom (Fisher et al., 1968).

\section{Results and Discussion \\ Biochemical parameters \\ Chlorophyll a}

The results pertaining of the effect applied through different PGPRs (PR3, PR5, PR6, PR24 and PR29) on chlorophyll 'a' $(\mathrm{mg} / \mathrm{g})$ fresh weight of Tomato are graphically presented in Table 3. PR3-PGPRs (PR3) application significantly influenced the chlorophyll ' $\mathrm{a}$ ' ( $\mathrm{mg} / \mathrm{g})$ fresh weight over control. Table 3 reveals that the maximum chlorophyll ' $a$ ' (mg/g) fresh weight (1.52) was recorded with $\mathrm{T}_{7}$ (PR3+NPK $100 \%+F Y M 100 \%)$ followed by (1.47) in $\mathrm{T}_{8}$ (PR3+NPK $100 \%+$ FYM $75 \%$ ) i.e. which were significantly higher than other treatment. The lowest chlorophyll ' $\mathrm{a}$ ' $(\mathrm{mg} / \mathrm{g})$ fresh weight (1.05) was observed in treatment $\mathrm{T}_{0}$ (control). PGPRs (PR5) application significantly influenced the chlorophyll ' $a$ ' $(\mathrm{mg} / \mathrm{g})$ fresh weight over control. Table 3 reveals that the maximum chlorophyll ' $\mathrm{a}$ ' $(\mathrm{mg} / \mathrm{g})$ fresh weight (1.64) was recorded with $\mathrm{T}_{7}$ (PR5+NPK $100 \%+\mathrm{FYM} 100 \%$ ) followed by (1.60) in $\mathrm{T}_{8}$ (PR5+NPK 100\%+FYM 75\%) i.e. which were significantly higher than other treatment. The lowest chlorophyll 'a' (mg/g) fresh weight (1.05) was observed in treatment $\mathrm{T}_{0}$ (control). PGPRs (PR6) application significantly influenced the chlorophyll ' $\mathrm{a}$ ' ( $\mathrm{mg} / \mathrm{g})$ fresh weight over control. Table 3 reveals that the maximum chlorophyll ' $\mathrm{a}$ ' (mg/g) fresh weight (2.12) was recorded with $\mathrm{T}_{7}$ (PR6+NPK $100 \%+$ FYM $100 \%$ ) followed by (1.73) in $\mathrm{T}_{8}$ (PR6+NPK $100 \%+$ FYM $75 \%$ ) i.e. which were significantly higher than other treatment. The lowest chlorophyll ' $\mathrm{a}$ ' (mg/g) fresh weight (1.05) was observed in treatment $\mathrm{T}_{0}$ (control). PGPRs (PR24) application significantly influenced the chlorophyll ' $a$ ' $(\mathrm{mg} / \mathrm{g})$ fresh weight over control. Table 3 reveals that the maximum chlorophyll ' $\mathrm{a}$ ' $(\mathrm{mg} / \mathrm{g})$ fresh weight (1.60) was recorded with $\mathrm{T}_{7}$ (PR24+NPK 100\%+FYM 100\%) followed by (1.53) in $\mathrm{T}_{8}$ (PR24+NPK $100 \%+\mathrm{FYM} 75 \%$ ) i.e. which were significantly higher than other treatment. The lowest chlorophyll 'a' (mg/g) fresh weight (1.05) was observed in treatment $\mathrm{T}_{0}$ (control). PGPRs (PR29) application significantly influenced the chlorophyll ' $\mathrm{a}$ ' (mg/g) fresh weight over control. Table 3 reveals that the maximum chlorophyll 'a' (mg/g) fresh weight (1.82) was recorded with $\mathrm{T}_{7}$ (PR29+NPK 100\%+FYM 100\%) followed by (1.69) in $\mathrm{T}_{8}$ (PR29+ NPK 100\% FYM 75\%) i.e. which were significantly higher than other treatment. The lowest chlorophyll 'a' (mg/g) fresh weight (1.05) was observed in treatment T0 (control). Bacterial inoculations (Azospirillum) improved the Tomato growth and biochemical parameters. The performance of the plants was better in inoculated treatments in comparison to the control. These results similar finding were recorded by (Kannahi and Ramya 2015; Rajput and Ramtake 2019) ${ }^{[4,7] .}$

\section{Chlorophyll 'b'}

The results pertaining of the effect applied through different PGPRs (PR3, PR5, PR6, PR24 and PR29) on chlorophyll ' $b$ ' $(\mathrm{mg} / \mathrm{g})$ fresh weight of Tomato are graphically presented in Table 4. PGPRs (PR3) application significantly influenced the chlorophyll ' $b$ ' $(\mathrm{mg} / \mathrm{g})$ fresh weight over control. Table 4 reveals that the maximum chlorophyll ' $b$ ' $(\mathrm{mg} / \mathrm{g})$ fresh weight (1.50) was recorded with $\mathrm{T}_{7}$ (PR3+NPK 100\%+FYM 100\%) followed by (1.43) in $\mathrm{T}_{8}(\mathrm{PR} 3+\mathrm{NPK} 100 \%+\mathrm{FYM} 75 \%)$ i.e. which were significantly higher than other treatment. The lowest chlorophyll 'b' (mg/g) fresh weight (0.70) was observed in treatment $\mathrm{T}_{0}$ (control). PGPRs (PR5) application significantly influenced the chlorophyll ' $b$ ' $(\mathrm{mg} / \mathrm{g})$ fresh weight over control. Table 4 reveals that the maximum chlorophyll ' $b$ ' (mg/g) fresh weight (1.67) was recorded with $\mathrm{T}_{7}$ (PR5+NPK 100\%+FYM 100\%) followed by (1.65) in $\mathrm{T}_{8}$ (PR5+NPK 100\%+FYM 75\%) i.e. which were significantly higher than other treatment. The lowest chlorophyll ' $b$ ' $(\mathrm{mg} / \mathrm{g})$ fresh weight $(0.70)$ was observed in treatment $\mathrm{T}_{0}$ (control). PGPRs (PR6) application significantly influenced the chlorophyll ' $b$ ' (mg/g) fresh weight over control. Table 4 reveals that the maximum chlorophyll ' $\mathrm{b}$ ' $(\mathrm{mg} / \mathrm{g})$ fresh weight (2.02) was recorded with $\mathrm{T}_{7}$ (PR26+NPK 100\%+FYM 100\%) followed by (1.80) in $\mathrm{T}_{8}$ (PR6+NPK 100\%+FYM 75\%) i.e. which were significantly higher than other treatment. The lowest chlorophyll 'b' (mg/g) fresh weight (0.70) was observed in treatment $\mathrm{T}_{0}$ (control). PGPRs (PR24) application significantly influenced the chlorophyll ' $b$ ' (mg/g) fresh weight over control. Table 4 reveals that the maximum chlorophyll ' $b$ ' (mg/g) fresh weight (1.60) was recorded with $\mathrm{T}_{7}$ (PR24+NPK 100\%+FYM 100\%) followed by (1.51) in $\mathrm{T}_{8}$ (PR24+NPK 100\%+FYM 75\%) i.e. which were significantly higher than other treatment. The lowest chlorophyll ' $b$ ' $(\mathrm{mg} / \mathrm{g})$ fresh weight $(0.70)$ was observed in treatment $\mathrm{T}_{0}$ (control). PGPRs (PR29) application significantly influenced the chlorophyll 'b' (mg/g) fresh weight over control. Table 4 reveals that the maximum chlorophyll ' $b$ ' $(\mathrm{mg} / \mathrm{g})$ fresh weight (1.80) was recorded with $\mathrm{T}_{7}$ (PR29+NPK 100\%+FYM 100\%) followed by (1.72) in $\mathrm{T}_{8}$ (PR29+ NPK 100\% FYM 75\%) i.e. which were significantly higher than other treatment. The lowest chlorophyll ' $\mathrm{b}$ ' (mg/g) fresh weight $(0.70)$ was observed in treatment $\mathrm{T}_{0}$ (control). Bacterial inoculations (Azospirillum) improved the Tomato growth and biochemical parameters. The performance of the plants was better in inoculated treatments in comparison to the control. These results similar finding were recorded by Kannahi and Ramya $(2015)^{[4]}$.

\section{Total chlorophyll}

The results pertaining of the effect applied through different PGPRs (PR3, PR5, PR6, PR24 and PR29) on Total chlorophyll $(\mathrm{mg} / \mathrm{g})$ fresh weight of Tomato are graphically presented in Table 5. PGPRs (PR3) application significantly influenced the Total chlorophyll $(\mathrm{mg} / \mathrm{g})$ fresh weight over control. Table 5 and reveals that the maximum Total chlorophyll (mg/g) fresh weight (3.05) was recorded with $\mathrm{T}_{7}$ (PR3+NPK 100\%+FYM 100\%) followed by (2.90) in $\mathrm{T}_{8}$ (PR3+NPK 100\%+FYM 75\%) i.e. which were significantly higher than other treatment. The lowest Total chlorophyll $(\mathrm{mg} / \mathrm{g})$ fresh weight (1.75) was observed in treatment $\mathrm{T}_{0}$ (control). PGPRs (PR5) application significantly influenced the Total chlorophyll (mg/g) fresh weight over control. Table 5 reveals that the maximum Total chlorophyll $(\mathrm{mg} / \mathrm{g})$ fresh weight (3.41) was recorded with $\mathrm{T}_{7}$ (PR5+NPK 100\%+FYM $100 \%$ ) followed by (3.20) in $\mathrm{T}_{8}$ (PR5+NPK 100\%+FYM 
$75 \%)$ i.e. which were significantly higher than other treatment. The lowest Total chlorophyll $(\mathrm{mg} / \mathrm{g})$ fresh weight (1.75) was observed in treatment $\mathrm{T}_{0}$ (control). PGPRs (PR6) application significantly influenced the Total chlorophyll $(\mathrm{mg} / \mathrm{g})$ fresh weight over control. Table 5 reveals that the maximum Total chlorophyll (mg/g) fresh weight (4.14) was recorded with $\mathrm{T}_{7}(\mathrm{PR} 6+\mathrm{NPK} 100 \%+\mathrm{FYM} \mathrm{100 \% )} \mathrm{followed} \mathrm{by}$ (3.53) in $\mathrm{T}_{8}(\mathrm{PR} 6+\mathrm{NPK} 100 \%+\mathrm{FYM} 75 \%)$ i.e. which were significantly higher than other treatment. The lowest Total chlorophyll (mg/g) fresh weight (1.75) was observed in treatment $\mathrm{T}_{0} \quad$ (control). PGPRs (PR24) application significantly influenced the Total chlorophyll $(\mathrm{mg} / \mathrm{g})$ fresh weight over control. Table 5 reveals that the maximum Total chlorophyll (mg/g) fresh weight (3.27) was recorded with $\mathrm{T}_{7}$ (PR24+NPK 100\%+FYM 100\%) followed by (3.04) in $\mathrm{T}_{8}$ (PR24+NPK 100\%+FYM 75\%) i.e. which were significantly higher than other treatment. The lowest Total chlorophyll $(\mathrm{mg} / \mathrm{g})$ fresh weight (1.75) was observed in treatment $\mathrm{T}_{0}$ (control). PGPRs (PR29) application significantly influenced the Total chlorophyll (mg/g) fresh weight over control. Table 5 reveals that the maximum Total chlorophyll $(\mathrm{mg} / \mathrm{g})$ fresh weight (3.66) was recorded with $\mathrm{T}_{7}$ (PR29+NPK 100\%+FYM $100 \%$ ) followed by (3.41) in $\mathrm{T}_{8}$ (PR29+ NPK 100\% FYM $75 \%)$ i.e. which were significantly higher than other treatment. The lowest Total chlorophyll $(\mathrm{mg} / \mathrm{g})$ fresh weight (1.75) was observed in treatment $\mathrm{T}_{0}$ (control).Bacterial inoculations (Azospirillum) improved the Tomato growth and biochemical parameters. The performance of the plants was better in inoculated treatments in comparison to the control. These results similar finding were recorded by Kannahi and Ramya (2015) ${ }^{[4]}$.

\section{Carotenoid}

The results pertaining of the effect applied through different PGPRs (PR3,PR5,PR6,PR24 and PR29) on carotenoid (mg/g) fresh weight of Tomato are graphically presented in Table 6. PGPRs (PR3) application significantly influenced the carotenoid $(\mathrm{mg} / \mathrm{g})$ fresh weight over control. Table 6 reveals that the maximum carotenoid $(\mathrm{mg} / \mathrm{g})$ fresh weight (1.61) was recorded with $\mathrm{T}_{7}(\mathrm{PR} 3+\mathrm{NPK} 100 \%+\mathrm{FYM} 100 \%)$ followed by (1.46) in $\mathrm{T}_{8}(\mathrm{PR} 3+\mathrm{NPK} 100 \%+\mathrm{FYM} 75 \%)$ i.e. which were significantly higher than other treatment. The lowest carotenoid (mg/g) fresh weight (0.82) was observed in treatment $\mathrm{T}_{0}$ (control). PGPRs (PR5) application significantly influenced the carotenoid $(\mathrm{mg} / \mathrm{g})$ fresh weight over control. Table 6 reveals that the maximum carotenoid $(\mathrm{mg} / \mathrm{g})$ fresh weight (1.67) was recorded with $\mathrm{T}_{7}$ (PR5+NPK 100\%+FYM $100 \%$ ) followed by (1.55) in $\mathrm{T}_{8}$ (PR5+NPK 100\%+FYM $75 \%)$ i.e. which were significantly higher than other treatment. The lowest carotenoid $(\mathrm{mg} / \mathrm{g})$ fresh weight $(0.82)$ was observed in treatment $\mathrm{T}_{0}$ (control). PGPRs (PR6) application significantly influenced the carotenoid (mg/g) fresh weight over control. Table 6 reveals that the maximum carotenoid $(\mathrm{mg} / \mathrm{g})$ fresh weight $(2.06)$ was recorded with $\mathrm{T}_{7}$ (PR6+NPK 100\%+FYM 100\%) followed by (1.74) in $\mathrm{T}_{8}$ (PR6+NPK 100\%+FYM 75\%) i.e. which were significantly higher than other treatment. The lowest carotenoid $(\mathrm{mg} / \mathrm{g})$ fresh weight $(0.82)$ was observed in treatment $\mathrm{T}_{0}$ (control). PGPRs (PR24) application significantly influenced the carotenoid $(\mathrm{mg} / \mathrm{g})$ fresh weight over control. Table 6 reveals that the maximum carotenoid (mg/g) fresh weight (1.64) was recorded with $\mathrm{T}_{7}(\mathrm{PR} 24+\mathrm{NPK} 100 \%+\mathrm{FYM} 100 \%)$ followed by (1.50) in $\mathrm{T}_{8}$ (PR24+NPK $100 \%+\mathrm{FYM} \mathrm{75 \% )}$ i.e. which were significantly higher than other treatment. The lowest carotenoid $(\mathrm{mg} / \mathrm{g})$ fresh weight $(0.82)$ was observed in treatment $\quad \mathrm{T}_{0} \quad$ (control). PGPRs $\quad$ (PR29) application significantly influenced the carotenoid $(\mathrm{mg} / \mathrm{g})$ fresh weight over control. Table 6 reveals that the maximum carotenoid $(\mathrm{mg} / \mathrm{g})$ fresh weight (1.78) was recorded with $\mathrm{T}_{7}(\mathrm{PR} 29+\mathrm{NPK}$ $100 \%+$ FYM $100 \%)$ followed by $(1.63)$ in $\mathrm{T}_{8}(\mathrm{PR} 29+\mathrm{NPK}$ $100 \%$ FYM $75 \%$ ) i.e. which were significantly higher than other treatment. The lowest carotenoid $(\mathrm{mg} / \mathrm{g})$ fresh weight (0.82) was observed in treatment $\mathrm{T}_{0}$ (control). Bacterial inoculations (Azospirillum) improved the Tomato growth and biochemical parameters. The performance of the plants was better in inoculated treatments in comparison to the control. These results similar finding were recorded by Kannahi and Ramya (2015) ${ }^{[4]}$.

\section{Yield and yield attributes}

PGPRs (PR3) application significantly influenced the number of fruit/plant over control. Fig. 1 reveals that the maximum number of fruit/plant (13.67) was recorded with $\mathrm{T}_{7}$ (PR3+NPK 100\%+FYM 100\%) followed by (12.67) in $\mathrm{T}_{8}$ (PR3+NPK 100\%+FYM 75\%) i.e. which were significantly higher than other treatment. The lowest number of fruit/plant (7.00) was observed in treatment $\mathrm{T}_{0}$ (control). PGPRs (PR5) application significantly influenced the number of fruit/plant over control. Fig. 1 reveals that the maximum number of fruit/plant (14.67) was recorded with $\mathrm{T}_{7} \quad$ (PR5+NPK $100 \%+$ FYM $100 \%$ ) followed by (13.67) in $\mathrm{T}_{8}$ (PR5+NPK $100 \%+$ FYM $75 \%$ ) i.e. which were significantly higher than other treatment. The lowest number of fruit/plant (7.00) was observed in treatment $\mathrm{T}_{0}$ (control). PGPRs (PR6) application significantly influenced the number of fruit/plant over control. Table 4.8 and fig 4.8 reveals that the maximum number of fruit/plant (17.00) was recorded with $\mathrm{T}_{7} \quad$ (PR6+NPK $100 \%+$ FYM 100\%) followed by (14.67) in $\mathrm{T}_{8}$ (PR6+NPK $100 \%+$ FYM $75 \%)$ i.e. which were significantly higher than other treatment. The lowest number of fruit/plant (7.00) was observed in treatment $\mathrm{T}_{0}$ (control). PGPRs (PR24) application significantly influenced the number of fruit/plant over control. Fig 1 reveals that the maximum number of fruit/plant (14.00) was recorded with $\mathrm{T}_{7}$ (PR24+NPK 100\%+FYM 100\%) followed by (13.33) in $\mathrm{T}_{8}$ (PR24+NPK 100\%+FYM 75\%) i.e. which were significantly higher than other treatment. The lowest number of fruit/plant (7.00) was observed in treatment $\mathrm{T}_{0}$ (control). PGPRs (PR29) application significantly influenced the number of fruit/plant over control. Fig 1 reveals that the maximum number of fruit/plant (15.00) was recorded with $\mathrm{T}_{7}(\mathrm{PR} 29+\mathrm{NPK} 100 \%+\mathrm{FYM} 100 \%)$ followed by (14.00) in $\mathrm{T}_{8}$ (PR23+ NPK $100 \%$ FYM 75\%) i.e. which were significantly higher than other treatment. The lowest number of fruit/plant (7.00) was observed in treatment $\mathrm{T}_{0}$ (control). In pot culture, and field trials $P$. fluorescence (SS5) enhanced the growth of tomato plants. Significant increase in root and shoot weight, length, fruit yield per plant, and total fruit yield was recorded. The strain SS5 was significantly rhizopheric competent and stabilized in the rhizosphere, without disturbing thenormal indigenous bacterial population (Ahirwar, et al., 2015; Rajput and Ramteke 2019) ${ }^{[7]}$.

PGPRs (PR3) application significantly influenced the fresh fruit weight (g/plant) over control. Fig. 2 reveals that the maximum fruit weight (g/plant) $(647.00 \mathrm{~g})$ was recorded with $\mathrm{T}_{7}$ (PR3+NPK 100\%+FYM 100\%) followed by $(556.67 \mathrm{~g})$ in $\mathrm{T}_{8} \quad$ (PR3+NPK $\left.100 \%+\mathrm{FYM} \quad 75 \%\right)$ i.e. which were significantly higher than other treatment. The lowest fruit weight ( $\mathrm{gm}$ ) (353.33) was observed in treatment $\mathrm{T}_{0}$ (control). PGPRs (PR5) application significantly influenced the fresh fruit weight (g/plant) over control. Fig 2 reveals that the 
maximum fruit weight (g/plant) $(682.33 \mathrm{~g})$ was recorded with $\mathrm{T}_{7}$ (PR5+NPK 100\%+FYM 100\%) followed by $(597.33 \mathrm{~g})$ in $\mathrm{T}_{8} \quad$ (PR5+NPK 100\%+FYM 75\%) i.e. which were significantly higher than other treatment. The lowest fresh fruit weight (g/plant) $\left(353.33 \mathrm{~g}\right.$ ) was observed in treatment $\mathrm{T}_{0}$ (control). Similar type of results also observed for other PGPR. In pot culture, and field trials $P$. fluorescence (SS5) enhanced the growth of tomato plants. Significant increase in root and shoot weight, length, fruit yield per plant, and total fruit yield was recorded. The strain SS5 was significantly rhizopheric competent and stabilized in the rhizosphere, without disturbing thenormal indigenous bacterial population (Ahirwar et al., 2015; Rajput and Ramteke 2019) ${ }^{[7]}$.

Table 1: Treatment details

\begin{tabular}{|c|c|c|c|}
\hline S. No & Treatments & Recommended Dose & Applied to Soil (t/ha) \\
\hline 1 & PGPR & $------1.0 \%$ volume for 5-10min \\
\hline 2 & FYM & $10 \mathrm{t} / \mathrm{ha}$ & Seed treatment $-1.0 \%$ volume for $5-10 \mathrm{~min}+50 \%$ of recommended \\
\hline 3 & NPK & $120: 60: 50 \mathrm{~kg} / \mathrm{ha}$ & doses all organic sources and inorganic fertilizer \\
\hline
\end{tabular}

Table 2: Treatment combination of PGPR with FYM and NPK

\begin{tabular}{|c|c|c|}
\hline S. No. & Treatment & Treatment combinations for PR 3, PR5, PR 6, PR 24 and 29 \\
\hline 1 & T0 & Control \\
\hline 2 & T1 & PGPR \\
\hline 3 & T2 & PGPR+NPK \\
\hline 4 & T3 & PGPR+FYM $(100 \%)$ \\
\hline 5 & T4 & PGPR+FYM $(75 \%)$ \\
\hline 6 & T5 & PGRR+FYM $(50 \%)$ \\
\hline 7 & T6 & PGPR+NPK $(100 \%)+F Y M(100 \%)$ \\
\hline 8 & T7 & PGPR+NPK $(100 \%)+F Y M(75 \%)$ \\
\hline 9 & T8 & PGPR+NPK $(100 \%)+F Y M(50 \%)$ \\
\hline 10 & T9 & PGPR+NPK $(100 \%)+F Y M(25 \%)$ \\
\hline 11 & T10 & \\
\hline
\end{tabular}

Table 3: Effect of PGPRs (PR3, PR5, PR6, PR24 and PR29) on chlorophyll 'a' of Tomato (Solanum lycopersicum L. Mill.) cv.NTL-186

\begin{tabular}{|c|c|c|c|c|c|}
\hline \multirow{2}{*}{ Treatments } & \multicolumn{5}{|c|}{ Chlorophyll 'a'(mg./g)FW } \\
\cline { 2 - 6 } & PR3 & PR5 & PR6 & PR24 & PR29 \\
\hline Control & 1.05 & 1.05 & 1.05 & 1.05 & 1.05 \\
\hline PGPR & 1.12 & 1.25 & 1.34 & 1.18 & 1.31 \\
\hline PGPR+NPK (100\%) & 1.17 & 1.31 & 1.42 & 1.22 & 1.37 \\
\hline PGPR+FYM (100\%) & 1.28 & 1.42 & 1.50 & 1.37 & 1.48 \\
\hline PGPR+FYM (75\%) & 1.26 & 1.38 & 1.45 & 1.33 & 1.42 \\
\hline PGPR+FYM (50\%) & 1.24 & 1.34 & 1.44 & 1.31 & 1.40 \\
\hline PGPR+FYM (25\%) & 1.15 & 1.27 & 1.40 & 1.20 & 1.33 \\
\hline PGPR+NPK+FYM(100\%) & 1.52 & 1.64 & 2.12 & 1.60 & 1.82 \\
\hline PGPR+NPK+FYM(75\%) & 1.47 & 1.60 & 1.73 & 1.53 & 1.69 \\
\hline PGPR+NPK+FYM(50\%) & 1.41 & 1.55 & 1.65 & 1.50 & 1.60 \\
\hline PGPR+NPK+FYM(25\%) & 1.37 & 1.51 & 1.61 & 1.42 & 1.55 \\
\hline CD (0.05\%) & 0.22 & 0.18 & 0.18 & 0.19 & 0.22 \\
\hline
\end{tabular}

Table 4: Effect of PGPRs (PR3, PR5, PR6, PR24 and PR29) on chlorophyll 'b' of Tomato (Solanum lycopersicum L. Mill.) cv.NTL-186

\begin{tabular}{|c|c|c|c|c|c|}
\hline \multirow{2}{*}{ Treatments } & \multicolumn{5}{|c|}{ Chlorophyll 'b'(mg./g)FW } \\
\cline { 2 - 6 } & PR3 & PR5 & PR6 & PR24 & PR29 \\
\hline Control & 0.70 & 0.70 & 0.70 & 0.70 & 0.70 \\
\hline PGPR & 0.83 & 0.97 & 1.17 & 0.85 & 1.05 \\
\hline PGPR+NPK (100\%) & 0.97 & 1.14 & 1.25 & 1.07 & 1.23 \\
\hline PGPR+FYM (100\%) & 1.15 & 1.25 & 1.39 & 1.18 & 1.31 \\
\hline PGPR+FYM (75\%) & 1.07 & 1.19 & 1.35 & 1.11 & 1.30 \\
\hline PGPR+FYM (50\%) & 1.02 & 1.15 & 1.28 & 1.08 & 1.24 \\
\hline PGPR+FYM (25\%) & 0.95 & 1.11 & 1.22 & 1.04 & 1.18 \\
\hline PGPR+NPK+FYM(100\%) & 1.50 & 1.67 & 2.02 & 1.60 & 1.80 \\
\hline PGPR+NPK+FYM(75\%) & 1.43 & 1.65 & 1.80 & 1.51 & 1.72 \\
\hline PGPR+NPK+FYM(50\%) & 1.36 & 1.48 & 1.63 & 1.40 & 1.56 \\
\hline PGPR+NPK+FYM(25\%) & 1.25 & 1.38 & 1.53 & 1.31 & 1.46 \\
\hline CD (0.05\%) & 0.22 & 0.25 & 0.18 & 0.29 & 0.38 \\
\hline
\end{tabular}


Table 5: Effect of PGPRs (PR3, PR5, PR6, PR24 and PR29) on Total chlorophyll of Tomato (Solanum lycopersicum L. Mill.) cv.NTL-186

\begin{tabular}{|c|c|c|c|c|c|}
\hline \multirow{2}{*}{ Treatments } & \multicolumn{5}{|c|}{ Total chlorophyll (mg/g) FW } \\
\cline { 2 - 6 } & PR3 & PR5 & PR6 & PR24 & PR29 \\
\hline Control & 1.75 & 1.75 & 1.75 & 1.79 & 1.74 \\
\hline PGPR & 1.95 & 2.22 & 2.51 & 2.24 & 2.01 \\
\hline PGPR+NPK (100\%) & 2.14 & 2.45 & 2.67 & 2.47 & 2.58 \\
\hline PGPR+FYM (100\%) & 2.43 & 2.66 & 2.89 & 2.68 & 2.84 \\
\hline PGPR+FYM (75\%) & 2.33 & 2.57 & 2.80 & 2.44 & 2.75 \\
\hline PGPR+FYM (50\%) & 2.26 & 2.49 & 2.72 & 2.42 & 2.49 \\
\hline PGPR+FYM (25\%) & 2.10 & 2.38 & 2.62 & 2.28 & 2.48 \\
\hline PGPR+NPK+FYM(100\%) & 3.05 & 3.41 & 4.14 & 3.27 & 3.66 \\
\hline PGPR+NPK+FYM(75\%) & 2.90 & 3.20 & 3.53 & 3.04 & 3.41 \\
\hline PGPR+NPK+FYM(50\%) & 2.77 & 3.03 & 3.27 & 2.91 & 3.16 \\
\hline PGPR+NPK+FYM(25\%) & 2.62 & 2.89 & 3.14 & 2.71 & 2.79 \\
\hline CD (0.05\%) & 0.34 & 0.29 & 0.28 & 0.20 & 0.26 \\
\hline
\end{tabular}

Table 6: Effect of PGPRs (PR3, PR5, PR6, PR24 and PR29) on Carotenoid of Tomato (Lycopersicon esculentum Mill.) cv.NTL-186

\begin{tabular}{|c|c|c|c|c|c|}
\hline \multirow{2}{*}{ Treatments } & \multicolumn{5}{|c|}{ Carotenoid (m/g) FW } \\
\cline { 2 - 6 } & PR3 & PR5 & PR6 & PR24 & PR29 \\
\hline Control & 0.82 & 0.82 & 0.82 & 0.82 & 0.82 \\
\hline PGPR & 0.88 & 1.02 & 1.16 & 0.96 & 1.03 \\
\hline PGPR+NPK (100\%) & 0.97 & 1.13 & 1.27 & 1.08 & 1.24 \\
\hline PGPR+FYM (100\%) & 1.19 & 1.30 & 1.38 & 1.26 & 1.34 \\
\hline PGPR+FYM (75\%) & 1.09 & 1.15 & 1.27 & 1.10 & 1.18 \\
\hline PGPR+FYM (50\%) & 1.03 & 1.12 & 1.23 & 1.07 & 1.15 \\
\hline PGPR+FYM (25\%) & 0.94 & 1.02 & 1.13 & 0.99 & 1.07 \\
\hline PGPR+NPK+FYM(100\%) & 1.61 & 1.67 & 2.06 & 1.64 & 1.78 \\
\hline PGPR+NPK+FYM(75\%) & 1.46 & 1.55 & 1.74 & 1.50 & 1.63 \\
\hline PGPR+NPK+FYM(50\%) & 1.38 & 1.46 & 1.64 & 1.42 & 1.53 \\
\hline PGPR+NPK+FYM(25\%) & 1.27 & 1.41 & 1.57 & 1.31 & 1.47 \\
\hline CD (0.05\%) & 0.24 & 0.23 & 0.19 & 0.13 & 0.56 \\
\hline
\end{tabular}

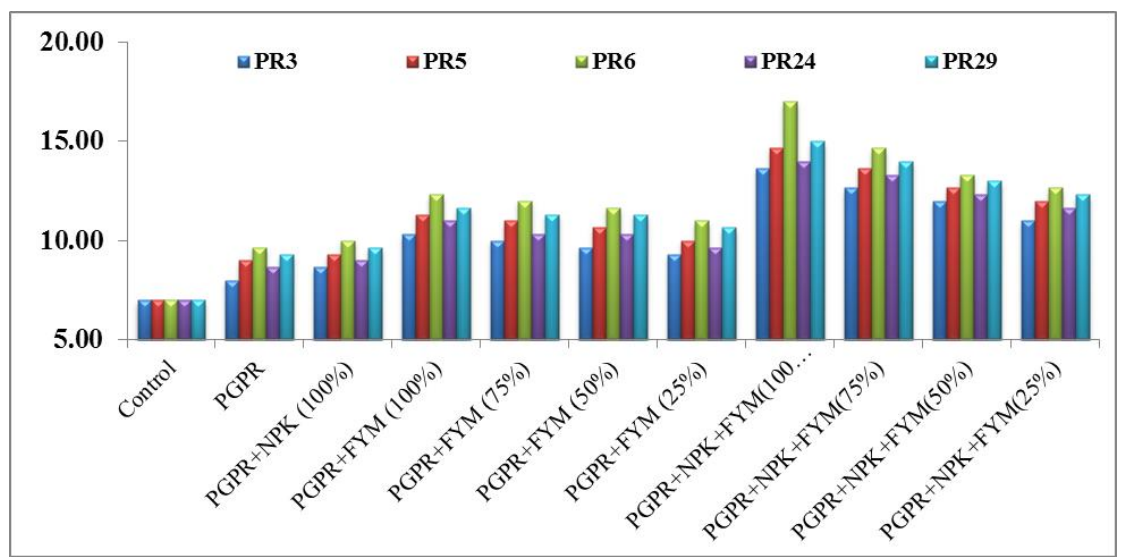

Fig 1: Effect of PGPRs (PR3, PR5, PR6, PR24 and PR29) on number of fruit/plant of Tomato cv. NTL-186

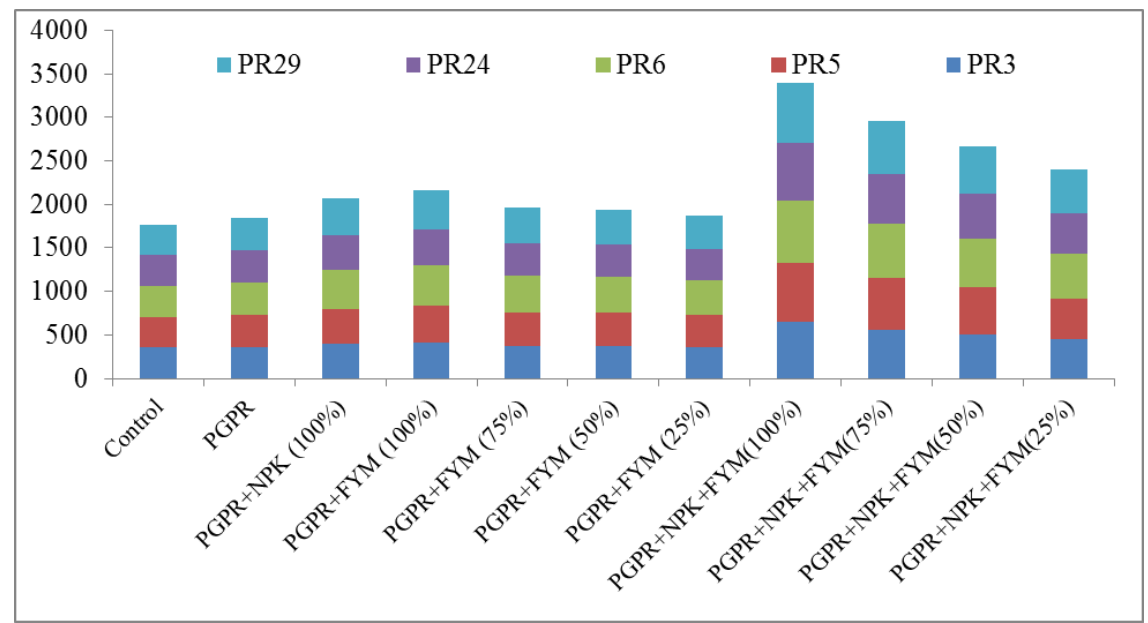

Fig. 1: Effect of PGPRs (PR3, PR5, PR6, PR24 and PR29) on fresh fruit weight (g/plant) of Tomato cv.NTL-186 


\section{Conclusion}

This study was conducted with the aim to understand the effects of different Plant Growth Promoting Rhizobacteria on biochemical content of Tomato cultivar NTL-186 in pot experiment. Significantly high chlorophyll a, b, Carotenoid content and yield attributes of tomato was observed with PGPR + NPK + FYM-100\% (T7) but it was statistically similar with PGPR+NPK+FYM-75\% (T8) in all strain of PGPRs. Hence it can be concluded as either T7 or T8 is best combinations for enhancing chlorophyll and Carotenoid content in tomato cultivar NTL-186.

\section{References}

1. Ali Q, Zameer M, Zahid H, Tabassum B, Nasir I, Saleem MH, Butt SJ. PGPR Potentially Improve Growth of Tomato Plants in Salt-Stressed Environment, Turkish Journal of Agriculture - Food Science and Technology 2016;4(6):455-463

2. Hillel D. Plant growth-promoting bacteria in agriculture and the environment, encyclopedia of soils in the environment, 2005, (Editor-in-Chief) D. Hillel, Elsevier, Oxford, U.K 2005;1:103-115, 2200.

3. Jenny $\mathrm{S}$, Malliga $\mathrm{P}$. Assessment of different concentrations of organic Manure on the growth and yield of Solanum lycopersicum L. (Tomato). IJIRSET DOI: 10.15680/IJIRSET, 2016, 3722-3731.

4. Kannahi M, Ramya R. Effect of biofertilizer, vermicompost, biocompost and chemical fertilizer on different morphological and phytochemical parameters of Lycopersicum esculentum L. World Journal of Pharmacy and Pharmaceutical Sciences 2015;4(09):1460-1469.

5. Naika S, Lidt de Jeude JV, Goffau M De, Hilmi M, Dam BV. Cultivation of tomato : production, processing and marketing. Agromisa Foundation and CTA, Wageningen 2005; 17:1-92

6. Peralta IE, Spooner DM. History, origin and early cultivation of tomato (Solanaceae), Genetic improvements of solanaceous crops: tomato, Science publisher 2007;2:1-24

7. Rajput GS, Ramteke PW. Impact of Plant Growth Promoting Rhizobacteria with FYM on the Growth, Yield Attribute and Yield of Tomato (Lycopersicon esculentum Mill.). Int. J Curr Microbiol App Sci 2019;8(09):2219-2232.

8. Ramakrishnan K, Selvakumar G. Effect of biofertilizers on enhancement of growth and yield on Tomato (Lycopersicum esculentum Mill.), International Journal of Research in Botany 2012;2(4):20-23

9. Sharafzadeh S. Effects of PGPR on growth and nutrients uptake of tomato. International Journal of Advances in Engineering \& Technology (@IJAET) 2012;2(1):27-31. 